\title{
The Nordic ICU Nursing Research Network
}

Ingrid Egerod, RN; MSN, PhD, Associate Professor, The University of Copenhagen, Faculty of Health Sciences and The University Hospitals Center for Nursing and Care Research, Copenhagen University Hospital Rigshospitalet, DK-2100 Copenhagen O, Denmark

Key Words: Databases * intensive care * networking * nursing * research *

E-mail: ie@ucsf.dk

\section{ESPAÑOL}

\section{La Red Nórdica de Investigación en Enfermería en UCI}

Palabras clave

Bases de datos, cuidado intensivo, red, enfermería, investigación Resumen

- Este artículo describe la formación y actividades de la Asociación Nórdica de Investigación en Enfermería en Cuidados Críticos.

- El objetivo de la asociación es apoyar y desarrollar la investigación en enfermería en cuidados críticos en los países Escandinavos.

- La asociación fue establecida en 2004 , organiza un congreso cada dos años y tiene un sitio web.

\section{SUMMARY}

- This paper describes the formation and activities of the Nordic Association for Intensive Care Nursing Research.

- The aim of the association is to support and develop intensive care nursing research in the Nordic countries.

- The association was established in 2004 , and holds biannual meetings and hosts a website.

\section{INTRODUCTION}

The European federation of Critical Care Nursing associations (EfCCNa) is a network of critical care nursing associations in Europe. EfCCNa was founded in 1999 and has 24 national member associations representing about 20,000 European critical care nurses. National and international conferences for critical care nurses promote practice, education, management and dissemination of research. This covers a lot of issues, but a group of academically prepared critical care nurses in the Scandinavian countries Denmark, Norway, and Sweden - needed a more specific focus on research methodology and networking within intensive care nursing.

\section{Building the network}

\section{Board members}

In 2003 a group of academically prepared intensive care nurses met in Lund, Sweden, and established the Nordic Association for Intensive Care Nursing Research (NOFI). A board was established and biannual meetings were planned for research dissemination and networking. Professor Ingegerd Bergbom (Sweden) chaired the board in 2003-2007 and since I have had that privilege (Denmark).
The meeting venues have rotated between Denmark, Norway and Sweden.

\section{Network members}

The board members invited research active or academically prepared intensive care unit (ICU) nurses in critical care to join the network and a membership fee was set (Bergbom et al. 2005). We initially included members from Denmark, Norway and Sweden in order to conduct meetings in the Scandinavian languages. This meant that Finland, Iceland, Greenland and the Faroe Islands did not participate initially. In the future, we plan to open the association to the rest of the Nordic countries and conduct some meetings in English. The network has expanded via the Internet and by word of mouth, and currently includes some 60-80 members.

\section{The network}

According to the NOFI statutes the aims are to:

- encourage nursing research in intensive care in the Nordic countries

- $\quad$ create a network of research active nurses

- $\quad$ exchange experiences across borders

- highlight Nordic intensive care nursing research.

Activities include biannual meetings, collaboration with Nordic organizations and maintaining an updated website.

\section{Website}

We established a website, www.nofi.info, with ongoing information on research and network activities. Each member was offered a research profile on the site and a logo was designed for the network (see above). Since we started the network we have had two volunteer webmasters. On the website the network members' research has been presented in three categories:

- the patient perspective

- the family perspective

- the professional perspective.

Using the network

\section{Biannual meetings}

Since 2004, NOFI has offered biannual thematic meetings for its members and others interested in the topics. A wide variety of themes has been covered at the meetings (see Table 1). Typically, each meeting has four presenters, each speaking for 45 minutes. In recent years, many newly graduated $\mathrm{PhD}$ researchers have presented their studies, which has been a valuable way to keep abreast of research in the field. We continue to try new ways of meeting with lectures and workshops. 


\begin{tabular}{|l|l|l|}
\hline Year & \multicolumn{1}{|c|}{ Venue } & \multicolumn{1}{c|}{ Topic } \\
\hline 2004 & Gothenburg, Sweden & $\begin{array}{l}\text { Acoustics and environmental stress in the } \\
\text { ICU }\end{array}$ \\
\hline 2004 & Copenhagen, Denmark & Relatives in the ICU \\
\hline 2005 & Tromsø, Norway & Ways of knowing in intensive care nursing \\
\hline 2005 & Malmö, Sweden & Sedation in ICU \\
\hline 2006 & Stockholm, Sweden & Ethical issues in intensive care \\
\hline 2006 & Oslo, Norway & Intensive care diaries and follow-up \\
\hline 2007 & Copenhagen, Denmark & Multimodal interventions in intensive care \\
\hline 2007 & Gothenburg, Sweden & $\begin{array}{l}\text { Research designs in intensive care nursing } \\
\text { studies }\end{array}$ \\
\hline 2008 & Oslo, Norway & Intensive care unit delirium \\
\hline 2008 & Copenhagen, Denmark & Psychometric instruments in ICU \\
\hline 2009 & Borås, Sweden & Burn unit nursing and relatives in ICU \\
\hline 2009 & Oslo, Norway & Themes of mechanical ventilation \\
\hline 2010 & Copenhagen, Denmark & Ethical issues in intensive care \\
\hline 2010 & Jönköping, Sweden & Rehabilitative initiatives in ICU \\
\hline 2011 & Copenhagen, Denmark & $\begin{array}{l}\text { The Nordic perspective in intensive care } \\
\text { nursing research }\end{array}$ \\
\hline 2011 & Halmstad, Sweden & Workshops on ICU issues \\
\hline
\end{tabular}

Table 1. NOFI biannual meetings

\section{Research and publications}

Several studies have been conducted in the NOFI network. We have explored the practice of intensive care diaries, which is a nursing initiative that started in the Scandinavian countries (Egerod et al. 2007; Akerman et al. 2010; Gjengedal et al. 2010; Egerod et al. 2011). Our current area of scholarship is conducting a metasynthesis of studies concerning the patient perspective of intensive care. A tradition of qualitative inquiry and patient perspective has existed in the Nordic countries and we wish to delve further into this area of research.

\section{Closing remarks}

The NOFI network will never become very large because the subspecialty of critical care is relatively small and the proportion of nurses conducting research in this area in the Nordic countries is even smaller. We often ask ourselves: is it necessary to have a network for research active and academically prepared nurses in addition to the national and international nursing and interdisciplinary critical care associations? We encourage integration of research and clinical practice in the other federations and societies (for example, EfCCNa and the European Society of Intensive Care Medicine) and perhaps one day NOFI will no longer be necessary. But for the present we need to support academic preparation in intensive and critical care nursing in the Nordic countries and NOFI has been a reliable engine in this process.

\section{Acknowledgments}

I would like to thank our webmasters Thomas Eriksson and Sue Harden, who have done terrific job of organising and maintaining the website, and the founders of NOFI: Ingegerd Bergbom, Anetth Granberg Axéll, Ingvar Fried and Eva Gjengedal; and the current board members Sissel Lisa Storli (vice chair and co-founder), Astrid Danielsen, Anetth Granberg Axéll, Maria Henricson, Berit Lindahl, Thomas Eriksson, and Anne Sophie Ågård (see photo). And finally, all NOFI members who have made the network possible.

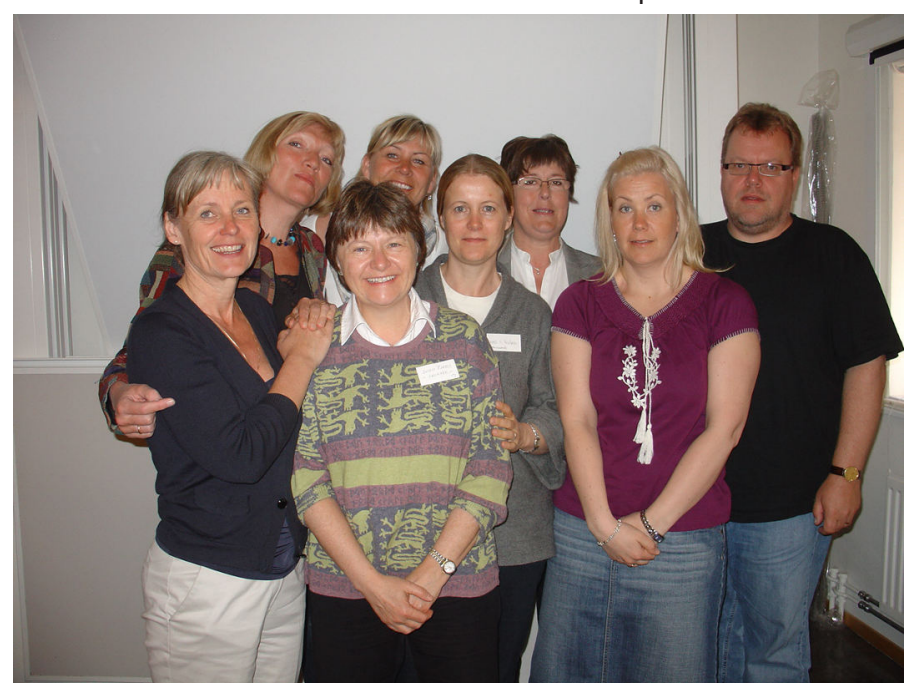

Photo: The current NOFI board members

\section{REFERENCES}

Akerman E, Granberg-Axell A, Ersson A, Fridlund B, Bergbom I (2010). Use and practice of patient diaries in Swedish intensive care units: a national survey. Nursing in Critical Care 15 (1), 26-33.

Bergbom I, Egerod I, Storli SL, Axèll AG (2005). Research platforms in the Nordic Association for Intensive Care Nursing Research (NOFI). Connect. The World of Critical Care Nursing 4 (3), 91-92

Egerod I, Schwartz-Nielsen KH, Hansen GM, Laerkner E (2007). The extent and application of patient diaries in Danish ICUs in 2006. Nursing in Critical Care 12 (3), 159-167.

Egerod I, Storli SL, Akerman E (2011). Intensive care patient diaries in Scandinavia: a comparative study of emergence and evolution. Nursing Inquiry [In press].

Gjengedal E, Storli SL, Holme AN, Eskerud RS (2010). An act of caring - patient diaries in Norwegian intensive care units. Nursing in Critical Care 15 (4), 176-184. 